\title{
Combination of Solid Phase Extraction and Flame Atomic Absorption Spectrometry for Trace Analysis of Cadmium
}

\author{
Ali A. Ensafi* and Ameneh Zendegi Shiraz.
}

\author{
College of Chemistry, Isfahan University of Technology, Isfahan 84156-83111, Iran
}

\begin{abstract}
Um novo método seletivo foi desenvolvido para a separação e pré-concentração de íons Cd(II) tendo como base a formação de um complexo em uma mini-coluna contendo como suporte carvão ativado modificado com laranja de xilenol. Os íons Cd(II) pré-concentrados foram eluídos com $5,0 \mathrm{~mL}$ de solução $0,5 \mathrm{~mol} \mathrm{~L}^{-1} \mathrm{HNO}_{3}$ e determinados por espectrometria de absorção atômica com chama. Foram estudadas as condições de preparo do carvão ativado modificado, $\mathrm{pH}$, vazões, bem como, o efeito de potenciais íons interferentes. Nas condições ótimas de trabalho, obteve-se um fator de pré-concentração de 200. O gráfico de calibração foi linear até $200 \mathrm{ng} \mathrm{mL}^{-1}$ de $\mathrm{Cd}$ (II) na solução inicial. O limite de detecção foi de $0,3 \mathrm{ng} \mathrm{mL}^{-1} \mathrm{Cd}(\mathrm{II})$ e o desvio padrão relativo (RSD \%) igual a 4,0\% para uma solução $20,0 \mathrm{ng} \mathrm{mL}^{-1} \mathrm{Cd}$ (II). O método foi aplicado com sucesso para determinar cádmio (II) em amostras de água e nos seguintes materiais de referência: lama de efluentes (CRM 144R) e água de mar (CASS 4).
\end{abstract}

A new selective method was developed for the separation and preconcentration of $\mathrm{Cd}(\mathrm{II})$ ions based on its complex formation with Xylenol orange loaded on activated carbon as a solid support in a mini-column. The preconcentrated ions were eluted by passing $5.0 \mathrm{~mL} 0.5 \mathrm{~mol} \mathrm{~L}^{-1} \mathrm{HNO}_{3}$ solution through the solid support and then the $\mathrm{Cd}(\mathrm{II})$ contents was measured by flame atomic absorption spectrometry. Conditions for preparation of the modified activated carbon, $\mathrm{pH}$ and flow variables were studied, as well as, the effect of potential interfering ions. A preconcentration factor of 200 was achieved using the optimum conditions. The calibration graph was linear up to 200 $\mathrm{ng} \mathrm{mL} \mathrm{m}^{-1} \mathrm{Cd}$ (II) in the initial solution. The detection limit of the method was $0.3 \mathrm{ng} \mathrm{mL}^{-1} \mathrm{Cd}$ (II) and the relative standard deviation (RSD\%) was $4.0 \%$ for $20.0 \mathrm{ng} \mathrm{mL}^{-1} \mathrm{Cd}(\mathrm{II})$. The method was successfully applied to the determination of cadmium(II) in water samples and in two reference materials: sewage sludge (CRM 144R), and sea water (CASS 4).

Keywords: cadmium, activated carbon, xylenol orange, solid phase extraction, FAAS

\section{Introduction}

The transition metals including cadmium are an important risk for human and animals. ${ }^{1,2}$ Because the main sources of heavy metals for humans and animals are the waters, ${ }^{3,4}$ reliable and sensitive analytical methods and procedures have an important role to evaluate the impacts of metal pollutants. Flame atomic absorption (FAAS) and emission spectrometry are the most widely methods used for trace metals determination. Due to the limited sensitivity of the FAAS, high dissolved solid content of saline waters, and to the low cadmium concentration levels in natural samples, its determination frequently requires a previous separation and preconcentration steps.

\footnotetext{
*e-mail: ensafi@cc.iut.ac.ir
}

Among the separation methods, solid-phase extraction (SPE) based on solid support modified with a suitable complexing agent is frequently used. Different solid phases with several complexing agents have been used for separation and preconcentration of $\mathrm{Cd}(\mathrm{II})$ as given in Table 1. Most of the reported methods has lower enrichment factor and/or suffer from many interfering ions for separation of $\mathrm{Cd}(\mathrm{II})$. Activated carbon is one of the important solid support that has been used either alone or modified with a complexing agent. In most of the previous studies, a ligand solution was needed for each experiment, because the chelating agent was used to wash metal ions from the surface of the sorbent.

The aim of this work is the development of a separation and preconcentration method for the determination of Cd(II) by FAAS for water samples, using activated carbon 
Table1. SPE preconcentration procedure for cadmium in combination with FAAS

\begin{tabular}{|c|c|c|c|c|c|c|c|c|}
\hline $\begin{array}{l}\text { Preconcentration } \\
\text { reagent }\end{array}$ & $\begin{array}{l}\text { Solid-phase } \\
\text { material }\end{array}$ & $\mathrm{pH}$ & $\begin{array}{l}\text { Calibration } \\
\text { range }\left(\mu \mathrm{g} \mathrm{L}^{-1}\right)\end{array}$ & $\begin{array}{c}\text { LOD } \\
\left(\mu \mathrm{g} \mathrm{L}^{-1}\right)\end{array}$ & $\begin{array}{l}\text { Enrichment } \\
\text { factor }\end{array}$ & Applications & Interferences & Ref. \\
\hline 5,7-Dibromo-quinoline-8-ol & Benzophenone & $6-8$ & $0.1-50$ & 0.1 & 200 & $\begin{array}{l}\text { Not reported. } \\
\text { Waste water }\end{array}$ & Soils, Sea \& & 5 \\
\hline Diazoaminobenzene(DAAB) & Poly-Cd(II)-DAAB-VP & 6 & $0.21-30$ & 0.21 & 200 & $\mathrm{Ca}^{2+}, \mathrm{Zn}^{2+}, \mathrm{Hg}^{2+}$ & $\begin{array}{c}\text { Tap \& } \\
\text { River water }\end{array}$ & 6 \\
\hline Bathocuproine disufonic acid & Chromosorb-108 & $8-9.5$ & $20-2000$ & 0.24 & $\mathrm{C}$ & $\begin{array}{c}\mathrm{Al}^{3+}, \mathrm{Ag}^{+}, \mathrm{Fe}^{3+}, \\
\mathrm{Cu}^{2+}, \mathrm{Mn}^{2+}, \mathrm{Zn}^{2+}, \\
\mathrm{Cr}^{3+}, \mathrm{Co}^{2+}, \mathrm{Ni}^{2+}, \mathrm{Pb}^{2+}\end{array}$ & $\begin{array}{l}\text { Tap \& River water, } \\
\text { Wine, Rice, } \\
\text { Tea, Honey }\end{array}$ & 7 \\
\hline 1-(2-pyridylazo)-2-naphthol & Chromosorb-106 & $8-9$ & - & 0.19 & 250 & $\begin{array}{l}\mathrm{Fe}^{3+}, \mathrm{Al}^{3+}, \mathrm{Mn}^{2+} \\
\mathrm{Zn}^{2+}, \mathrm{Cu}^{2+}, \mathrm{Cr}^{3+} \\
\quad \mathrm{Co}^{2+}, \mathrm{Ni}^{2+}\end{array}$ & $\begin{array}{c}\text { River water, } \\
\text { salt, tea, } \\
\text { Human hair, tobacco }\end{array}$ & 8 \\
\hline Iodide & $\begin{array}{l}\text { Naphthalene- } \\
\text { methyltrioctyl- } \\
\text { amonium chloride }\end{array}$ & $1.2-10$ & $1-100$ & 0.6 & 40 & - & $\begin{array}{c}\text { Tap \& Persian } \\
\text { Gulf water }\end{array}$ & 9 \\
\hline$O, O$-Diethyldithiophosphate & Amberlite XAD-4 & - & - & $1-5$ & 20 & Not investigated & Biological samples & 10 \\
\hline $\begin{array}{l}\text { 2-(62 -methyl-22 - } \\
\text { benzothioazolylazo) } \\
\text { chromatropic acid }\end{array}$ & Polyurethane foam & 7.5 & $10-1000$ & $0.8,2.04$ & 37,22 & $\mathrm{Fe}^{3+}$ & $\begin{array}{c}\text { Natural \& Tap water, } \\
\text { Tea, Spinach }\end{array}$ & 11 \\
\hline $\begin{array}{l}\text { Vermicompost } \\
\text { (humic material) }\end{array}$ & - & 5.0 & - & 5 & 100 & - & Mineral water & 12 \\
\hline Cupferron & Silica Gel & 5.5 & - & 0.5 & 30 & $\mathrm{Zn}^{2+}, \mathrm{Cu}^{2+}, \mathrm{Al}^{3+}$ & Nail polish & 13 \\
\hline Xylenol Orange & Amberlite XAD-7 & $4.5-5$ & $500-2500$ & 9 & 50 & - & River water & 18 \\
\hline Xylenol Orange & Activated carbon & 6.0 & $0.5-200$ & 0.3 & 200 & - & $\begin{array}{l}\text { Natural \& } \\
\text { Tap water }\end{array}$ & $\begin{array}{c}\text { Present } \\
\text { work }\end{array}$ \\
\hline
\end{tabular}

as sorbent and Xylenol orange (XO) as complexing agent. Activated carbon tightly adsorbed $\mathrm{XO}$ and thus, the adsorbed XO did not wash away during the elution step. This means that the modified activated carbon can be used several times without decreasing the enrichment factor.

\section{Experimental}

\section{Reagents}

All solutions were prepared with double distilled water. Otherwise stated, analytical-grade acids and other chemicals were obtained from Merck (Darmstadt, Germany).

Activated carbon, 40-60 mesh, was soaked in hydrochloric acid for 1 day; it was then washed with water and dried at $110{ }^{\circ} \mathrm{C}$ for 1 day.

Xylenol orange solution, $0.010 \%(\mathrm{~m} / \mathrm{v})$, was prepared by dissolving $0.010 \mathrm{~g}$ of the reagent in water. Samples were filtered through a cellulose membrane of pore size $<2 \mu \mathrm{m}$.

Universal buffer ( $\mathrm{pH}$ 3.0-11.0) was made of mixture of acetic acid, boric acid and phosphoric acid plus sodium hydroxide $\left(0.04 \mathrm{~mol} \mathrm{~L}^{-1}\right)$ in water.

The following certified reference materials were used: CASS.4 seawater (National Research Council of Canada, Ottawa, Ontario) and CRM 144 R Sewage Sludge from Domestic Origin (Community Bureau of Reference, Brussels, Belgium).

\section{Apparatus}

A Perkin-Elmer (USA), Model 2380 atomic absorption spectrometer furnished with a cadmium hollow-cathode lamp was used. The instrument was set at a wavelength of $228.8 \mathrm{~nm}$ and the air-acetylene flame was adjusted according to the standard conditions. The schematic diagram of the preconcentration system is shown in Figure 1. The hardware of the system was composed of a 32 channel I/O card (PCL-720, Advantech, Taiwan) which has a power relay module to convert the output of I/O card to $220 \mathrm{~V} \mathrm{AC}$, a peristaltic pump (Ismatec, ISM 404, Switzerland), three $220 \mathrm{~V}$ AC electrical valves, a silicon rubber tubing pump (2.06 $\mathrm{mm}$ i.d.) and a PC computer, Pentium II (233 MHz). A program was written in Borland $\mathrm{C}^{++}$by the authors to monitor and to control the system. The mini-column was made by packing of Teflon tubes ( $7 \mathrm{~mm}$ i.d.) with XO loaded activated carbon. Small amount of glass wool was plugged at the ends of each column to prevent material loss. A WPA Lightwave (UK), Model S2000 diode array UV-Vis spectrophotometer was used to measure the absorbance of the XO solution. The $\mathrm{pH}$ of aqueous solutions was checked using a Metrohm (Switzerland), Model 827 pH meter with a glass electrode.

\section{Preparation of modified activated carbon}

In a $1000 \mathrm{~mL}$ beaker, $2.0 \mathrm{~g}$ activated carbon was added to $800 \mathrm{~mL}$ of $\mathrm{XO}$ solution $(6.0 \mathrm{mg} / 100 \mathrm{~mL})$ and mixed well 


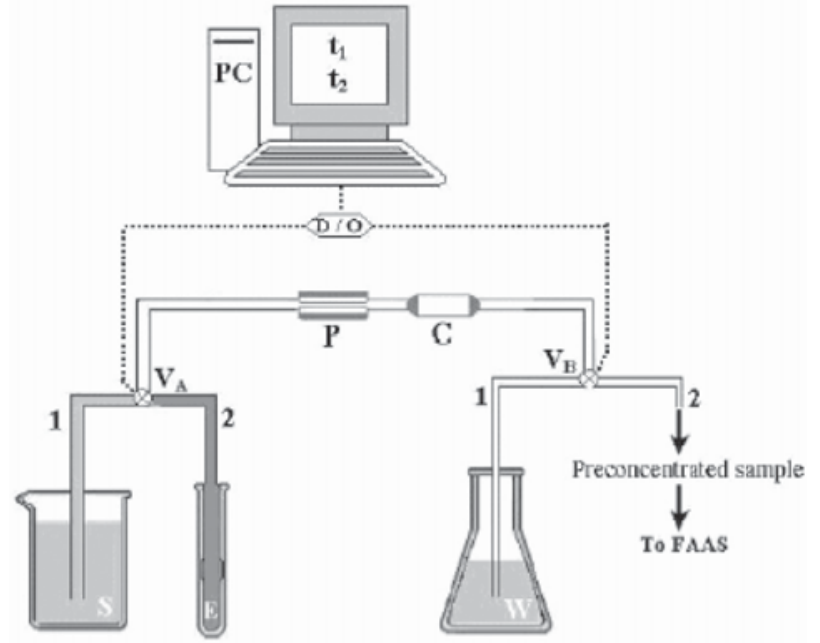

Figure 1. The schematic diagram of the preconcentration system. (P, Pump; C, Microcolumn; D/O: Analog to digital converter; S, Sample solution; $\mathrm{V}_{\mathrm{A}}$, valves $\mathrm{A} ; \mathrm{V}_{\mathrm{B}}$, valve $\mathrm{B}$; $\mathrm{E}$, Eluent solution $\left(0.50 \mathrm{~mol} \mathrm{~L}^{-1}\right.$ $\mathrm{HNO}_{3}$ ) and $\mathrm{PC}$, Computer).

at pH 10.0 (universal buffer, $0.04 \mathrm{~mol} \mathrm{~L}^{-1}$ ). After $36 \mathrm{~h}$, the mixture was filtered and washed with water three times, each time with $10 \mathrm{~mL}$ water, and then dried out. A Teflon column (42.9 cm length and $7.0 \mathrm{~mm}$ in diameter) was packed with $0.20 \mathrm{~g}$ of the modified activated carbon.

\section{Procedure}

The method was tested with model solution before its application to real samples. A $50-1000 \mathrm{~mL}$ of $\mathrm{Cd}$ (II) solution, buffered at $\mathrm{pH} 6.0$ (universal buffer, $0.04 \mathrm{~mol}$ $\mathrm{L}^{-1}$ ), was passed through the column at a flow rate of 4.0 $\mathrm{mL} \mathrm{min}^{-1}$ by opening the position 1 of electrical valves $\mathrm{A}$ and $\mathrm{B}$ (Figure 1). After finishing the sample solution, position 1 of valves $\mathrm{A}$ and $\mathrm{B}$ was closed, and position 2 of valves $\mathrm{A}$ and $\mathrm{B}$ was opened. Then, a volume of 5.0 $\mathrm{mL}$ of $0.50 \mathrm{~mol} \mathrm{~L}^{-1}$ nitric acid was passed through the column at a flow rate of $0.5 \mathrm{~mL} \mathrm{~min}^{-1}$ to elute the $\mathrm{Cd}(\mathrm{II})$ ions. The eluent was collected and $\mathrm{Cd}(\mathrm{II})$ was determined by flame atomic absorption spectrometry. The percent of metal ions adsorbed on the column for the concentration of $\mathrm{Cd}(\mathrm{II})$ was calculated from the amount of $\mathrm{Cd}(\mathrm{II})$ ions in the starting sample and the amount of Cd(II) eluted from the column.

The CASS4 Nearshore Seawater reference material for $\mathrm{Cd}(\mathrm{II})$ ions was analyzed. The $\mathrm{pH}$ of the sample was adjusted to 6 and the solution was passed through the column. Cadmium ions retained on the column were eluted with $5.0 \mathrm{~mL}$ of $0.5 \mathrm{~mol} \mathrm{~L}^{-1} \mathrm{HNO}_{3}$ and further introduced into the nebulizer of FAAS as described above.

For Sewage sludge, $100 \mathrm{mg}$ of CRM144R Sewage sludge standard reference material sample was decomposed with $16 \mathrm{~mL}$ of aqua regia and the solution was evaporated to dryness. ${ }^{14}$ This process was repeated twice. A volume of $10 \mathrm{~mL}$ of distilled water was added to the residue. The suspension was filtered through a blue band filtering paper and the insoluble residue was washed with distilled water. Afterwards, the above procedure was applied to the final solutions and the blank solution.

\section{Results and Discussion}

Xylenol orange (XO) (3,32 -bis[N,N-di(carboxymethyl) aminomethyl]-o-cresolsulfonephthalein) is a water-soluble dye of the triphenylmethane group. This is a metal indicator widely used for analytical determinations. ${ }^{15,16}$ Silica gel modified Xylenol orange have been used as a solid phase extractor for $\mathrm{Hg}(\mathrm{II}){ }^{17}$ and $\mathrm{Pb}(\mathrm{II}) .{ }^{18}$ Tewari et al. ${ }^{19}$ have used Amberlite XAD-7 impregnated with Xylenol orange as a chelating collector for preconcentration of $\mathrm{Cd}(\mathrm{II}), \mathrm{Co}(\mathrm{II})$, $\mathrm{Cu}(\mathrm{II}), \mathrm{Ni}(\mathrm{II}), \mathrm{Zn}(\mathrm{II})$ and $\mathrm{Fe}(\mathrm{III})$ at a $\mathrm{pH}$ range of 4-7. In the reported procedure, preparation of the solid phase needs long time (min. $2 \mathrm{~h}$ ), and the limit of quantification for $\mathrm{Cd}(\mathrm{II})$ was $10 \mu \mathrm{g} \mathrm{mL}^{-1}$. XO has a great formation constant with $\mathrm{Cd}(\mathrm{II})$. This ligand acts as a selective complexing agent for $\mathrm{Cd}(\mathrm{II})$ at $\mathrm{pH}$ 6.0. On the other hand, $\mathrm{XO}$ can be adsorbed on activated carbon surfaces. After the adsorption, the modified activated carbon is completely stable and does not wash off when using $\mathrm{H}_{2} \mathrm{O}$ or $\mathrm{HNO}_{3}$ solution as a washing solvent. This means that the activated carbon treated with XO can be used several times for separation and preconcentration of $\mathrm{Cd}(\mathrm{II})$ without decreasing the enrichment factor of the solid phase. This may be due to the similarity of the XO structure to that of activated carbon, producing strong $\pi-\pi$ interaction. ${ }^{20}$

\section{Optimization of variables}

First of all, to obtain the best quantitative recoveries of $\mathrm{Cd}$ (II) ions, many parameters such as $\mathrm{pH}$ of adsorption of $\mathrm{XO}$ on activated carbon, $\mathrm{pH}$ of sample solution, sample volume, type and volume and the concentration of washing solution, sample flow-rate through the column, capacity of the modified activated carbon and the effect of matrix on the preconcentration step should be studied. In the optimization steps, $0.20 \mathrm{~g}$ of activated carbon was used.

To find the optimum $\mathrm{pH}$ for adsorption of $\mathrm{XO}$ on the activated carbon, buffer solutions were used. For this purpose, $6.0 \mathrm{mg}$ of $\mathrm{XO}$ and $25.0 \mathrm{~mL}$ of buffer solutions $(\mathrm{pH}$ 4.0-11.0) were added into a series of $100 \mathrm{~mL}$ volumetric flasks and the solutions were diluted to $100 \mathrm{~mL}$ with water. The absorbances of the solutions were measured 
spectrophotometrically at an appropriate wavelength to find the molar absorption coefficient of $\mathrm{XO}$ at different $\mathrm{pH}$ values. Then, $6.0 \mathrm{mg}$ of $\mathrm{XO}$ and $25.0 \mathrm{~mL}$ of the buffer solutions ( $\mathrm{pH}$ 4.0-11.0) plus $0.20 \mathrm{~g}$ activated carbon were mixed in a series of $100 \mathrm{~mL}$ beakers. After $12 \mathrm{~h}$, the mixtures were filtered, and the absorbances of the filtered solutions were measured spectrophotometrically to find non-adsorbed $\mathrm{XO}$ in each solution, according to the calibration curve. The results are given in Table 2 . The results showed that the best $\mathrm{pH}$ for adsorption of $\mathrm{XO}$ on activated carbon was 10.0. Therefore, a buffer solution of pH 10.0 (universal buffer, $0.04 \mathrm{~mol} \mathrm{~L}^{-1}$ ) was used to prepare the modified activated carbon.

The influence of time on the modification of activated carbon was studied by treating $6.0 \mathrm{mg}$ of $\mathrm{XO}$ and $25.0 \mathrm{~mL}$ of buffer solution at $\mathrm{pH} 10.0$ and $0.20 \mathrm{~g}$ activated carbon for different times. The results showed that maximum adsorption of $\mathrm{XO}$ on the surface of activated carbon took place after $36 \mathrm{~h}$ (Figure 2).

The capacity of activated carbon for $\mathrm{XO}$ was also checked. In order to measure the capacity of activated carbon for adsorption of $\mathrm{XO}$ at $\mathrm{pH} 10.0,25 \mathrm{~mL}$ of the buffer solution ( $\mathrm{pH} 10.0$ ) plus 3.0 to $9.5 \mathrm{mg}$ of XO was added into a series of $100 \mathrm{~mL}$ beakers and $0.20 \mathrm{~g}$ activated

Table 2. Influence of $\mathrm{pH}$ on adsorption of $\mathrm{XO}$ on activated carbon

\begin{tabular}{lcc}
\hline $\mathrm{pH}$ & $\lambda_{\max } / \mathrm{nm}$ & Absorbance \\
\hline 4.0 & 433 & 0.150 \\
5.0 & 435 & 0.085 \\
6.0 & 438 & 0.052 \\
7.0 & 578 & 0.016 \\
8.0 & 578 & 0.015 \\
9.0 & 578 & 0.011 \\
10.0 & 578 & 0.004 \\
11.0 & 581 & 0.045 \\
\hline
\end{tabular}

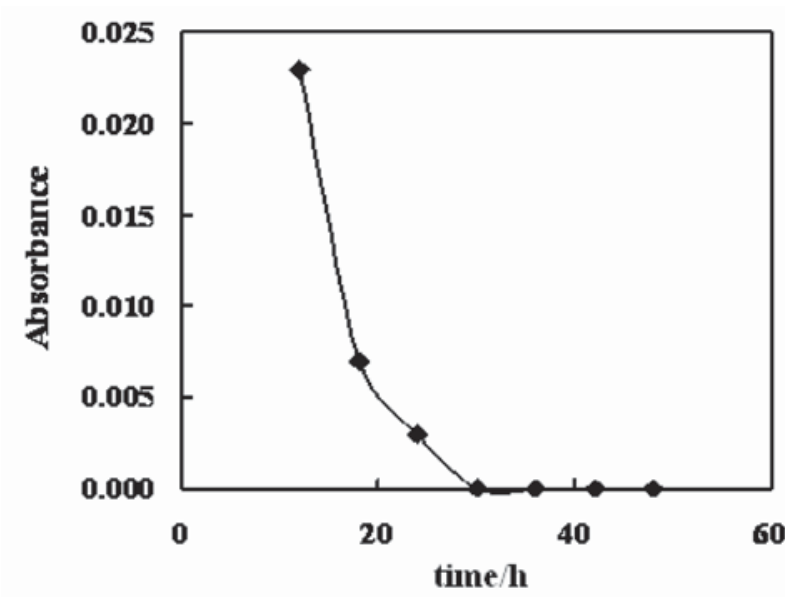

Figure 2. Influence of time on the modification of activated carbon with XO. Conditions: $100 \mathrm{mg}$ activated carbon; $6.0 \mathrm{mg} \mathrm{XO}$; at $\mathrm{pH}=10.0$. carbon was added to each beaker. After $36 \mathrm{~h}$, the mixtures were filtered, and the absorbances of each solution were measured spectrophotometrically to find the free XO (non-adsorbed). The results are shown in Figure 3. From the results, we can calculate that $1.0 \mathrm{~g}$ of activated carbon could adsorb $30.0 \mathrm{mg}$ of XO.

The influence of $\mathrm{pH}$ of sample solution on the preconcentration step of $\mathrm{Cd}(\mathrm{II})$ was also studied. For this purpose, $200 \mathrm{~mL}$ of $50.0 \mathrm{ng} \mathrm{mL}^{-1} \mathrm{Cd}(\mathrm{II})$ at different $\mathrm{pH}$ values (3.0-10.0) was passed through the modified solid phase. Then the eluent solution was checked for $\mathrm{Cd}(\mathrm{II})$ concentration using FAAS (Figure 4). The results showed that a suitable $\mathrm{pH}$ for adsorption of $\mathrm{Cd}(\mathrm{II})$ on the modified activated carbon is around 6.0. This is due to the fact that in acidic solution, the constant formation of the $\mathrm{Cd}(\mathrm{II})-\mathrm{XO}$ complex decreases due to the protonation of XO. Therefore,

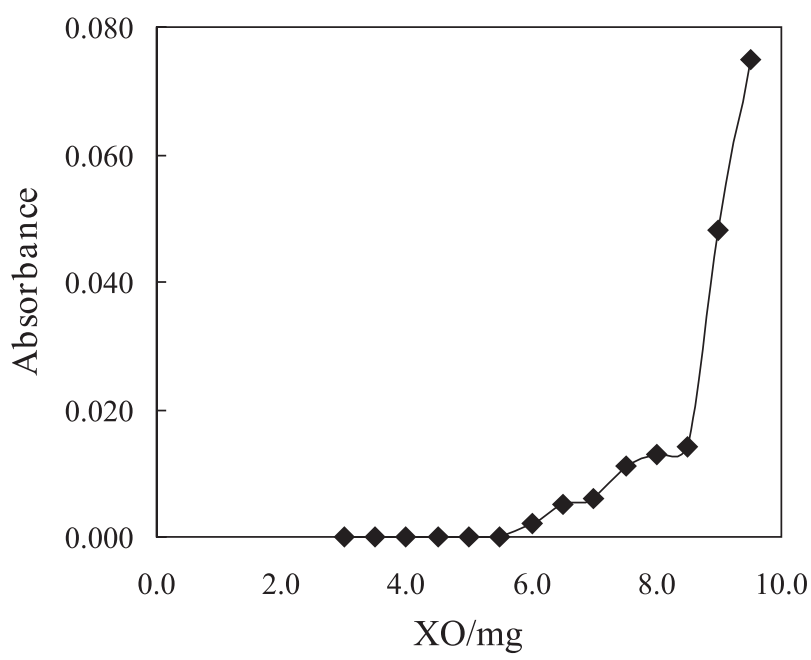

Figure 3. Capacity of activated carbon for XO. Conditions: $200 \mathrm{mg}$ activated carbon; at $\mathrm{pH}$ 10.0; mixed and stored for $36 \mathrm{~h}$.

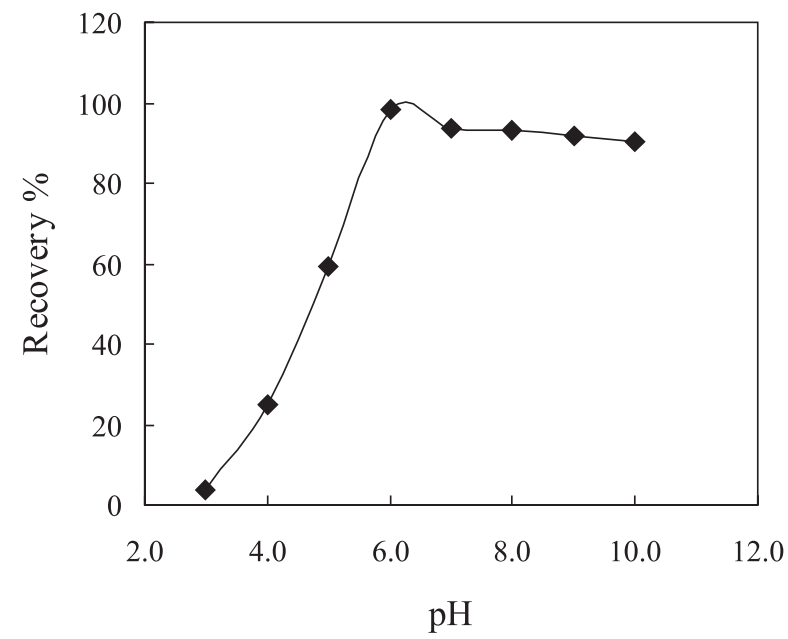

Figure 4. Influence of $\mathrm{pH}$ of the sample solution on adsorption of $\mathrm{Cd}(\mathrm{II})$ on the modified activated carbon. Conditions: Initial Cd(II) value, $200 \mathrm{~mL}$ of $50.0 \mathrm{ng} \mathrm{mL}-1$; Washing solution, $5 \mathrm{~mL}$ of $0.50 \mathrm{~mol} \mathrm{~L}^{-1} \mathrm{HNO}_{3}$. 
a buffer solution (universal, $0.04 \mathrm{~mol} \mathrm{~L}^{-1}$ ) at $\mathrm{pH} 6.0$ was used for the preconcentration step.

For desorption of $\mathrm{Cd}$ (II) from the solid phase, different $\mathrm{HNO}_{3}$ concentrations $(5.0 \mathrm{~mL})$ in the interval range of 0.5 to $2.0 \mathrm{~mol} \mathrm{~L}^{-1}$ with flow rate of $0.5 \mathrm{~mL} \mathrm{~min}^{-1}$ and with sample flow rate of $2.0 \mathrm{~mL} \mathrm{~min}{ }^{-1}$ were tested for the quantitative elution of the adsorbed $\mathrm{Cd}(\mathrm{II})$ ions from the column. The results showed that $0.5 \mathrm{~mol} \mathrm{~L}^{-1} \mathrm{HNO}_{3}$ was suitable to remove $(100 \pm 1.3) \%$ of $\mathrm{Cd}(\mathrm{II})$ from the solid sorbent. In order to optimize the volume of $0.5 \mathrm{~mol} \mathrm{~L}^{-1} \mathrm{HNO}_{3}$ solution, $50 \mathrm{~mL}$ of $200.0 \mathrm{ng} \mathrm{mL}^{-1} \mathrm{Cd}(\mathrm{II})$ was passed through a series of the modified activated carbon under the optimum conditions. Then the solid phases were washed with different volumes of $0.50 \mathrm{~mol} \mathrm{~L}^{-1} \mathrm{HNO}_{3}(2.0-6.0 \mathrm{~mL})$. The results showed that $5.0 \mathrm{~mL} 0.5 \mathrm{~mol} \mathrm{~L}^{-1} \mathrm{HNO}_{3}$ was suitable to remove $(100 \pm 1.5) \%$ of $\mathrm{Cd}(\mathrm{II})$ ions from the solid phase.

The influence of the sample flow rate on preconcentration efficiency of $\mathrm{Cd}(\mathrm{II})$ ions through the column was also investigated. For this purpose, a volume of $50 \mathrm{~mL}$ of $200.0 \mathrm{ng} \mathrm{mL}^{-1} \mathrm{Cd}$ (II) solution at $\mathrm{pH} 6.0$ was passed through a series of modified columns at different flow rates. Then the adsorbed Cd(II) was washed with $5 \mathrm{ml}$ of $0.5 \mathrm{~mol} \mathrm{~L}^{-1} \mathrm{HNO}_{3}$ solution and then the $\mathrm{Cd}(\mathrm{II})$ content was measured using FAAS. The results showed that using a sample flow rate greater than $5.0 \mathrm{~mL} \mathrm{~min}^{-1}$ caused a decrease of the $\mathrm{Cd}(\mathrm{II})$ ions recoveries from 100 to $95 \%$. Therefore, a sample flow rate of $4.0 \mathrm{~mL} \mathrm{~min}^{-1}$ was used for further studies.

The effect of flow rate of $\mathrm{HNO}_{3}\left(0.5 \mathrm{~mol} \mathrm{~L}^{-1}\right)$ on desorption efficiency of $\mathrm{Cd}$ (II) ions from the column was also checked in the range of $0.5-2.0 \mathrm{~mL} \mathrm{~min}^{-1}$. The results showed that the recovery of cadmium was maximized when using elution rates up to $0.5 \mathrm{~mL} \mathrm{~min}^{-1}$.

The capacity of the modified activated carbon for adsorption of $\mathrm{Cd}(\mathrm{II})$ was checked by passing $150 \mathrm{~mL}$ of $\mathrm{Cd}(\mathrm{II})$ solution containing 50.0-1000.0 $\mu \mathrm{g} \mathrm{L}^{-1} \mathrm{Cd}(\mathrm{II})$ through the column (containing $0.20 \mathrm{~g}$ modified activated carbon). The metal ions were stripped off the modified activated carbon with $5 \mathrm{~mL} 0.5 \mathrm{~mol} \mathrm{~L}^{-1} \mathrm{HNO}_{3}$ and measured by FAAS. The adsorption capacity was calculated as the following equation:

$$
\mathrm{Q}=\left(\mathrm{C}_{0}-\mathrm{C}_{\mathrm{e}}\right) \mathrm{v} / \mathrm{m}
$$

where $Q$ represents the adsorption capacity $\left(\mu \mathrm{g} \mathrm{g}^{-1}\right), C_{0}$ and $C_{\mathrm{e}}$ the initial and equilibrium concentration of $\mathrm{Cd}(\mathrm{II})$ $\left(\mu \mathrm{g} \mathrm{L}^{-1}\right), \mathrm{m}$ is mass of the modified activated carbon $(\mathrm{g})$ and $\mathrm{v}$ is the volume of metal ions solution $(\mathrm{L})$. The adsorbed $\mathrm{Cd}(\mathrm{II})$ on the solid phase was eluted with $5 \mathrm{ml}$ of $0.5 \mathrm{~mol} \mathrm{~L}^{-1} \mathrm{HNO}_{3}$ and the desorbed $\mathrm{Cd}(\mathrm{II})$ was measured using FAAS. As it can be seen in Figure 5, the amount of $\mathrm{Cd}(\mathrm{II})$ adsorbed on the solid phase increased with the initial concentration of $\mathrm{Cd}(\mathrm{II})$. In order to reach the saturation, the initial $\mathrm{Cd}(\mathrm{II})$ concentrations were increased till the plateau values (adsorption capacity values) were obtained. It was established that the capacity of the solid adsorbent is equal to $0.50 \mathrm{mg}$ of cadmium per $1.0 \mathrm{~g}$ of the modified activated carbon.

Reusability of the modified activated carbon was checked using the same solid phase for sorption-desorption of $\mathrm{Cd}(\mathrm{II})$ ions for fifty times the reusability was tested. The maximum change in the performance (sorption capacity) of the solid phase after the repeated use was less than $2 \%$, indicating that its repeated use is feasible as leaching of the dye from the activated carbon matrix is insignificant. No change in the sorption capacity of the modified activated carbon was noticed after storing it for 5 months.

Limit of quantitative preconcentration, preconcentration factor and limit of detection

The lower limit of quantitative preconcentration (or limit of quantification) was determined by loading a fixed amount of $\mathrm{Cd}(\mathrm{II})$ ions - $0.5 \mathrm{mg}$ for $\mathrm{Cd}(\mathrm{II})$ - onto the column containing $200 \mathrm{mg}$ of the solid phase from a varying volume of the feed solution ( 100 to $2000 \mathrm{~mL}$ ). The metal ions were desorbed as given in the recommended procedure into $5.0 \mathrm{~mL}$ of $0.5 \mathrm{~mol} \mathrm{~L}^{-1} \mathrm{HNO}_{3}$ and determined by FAAS. The results showed that the limit of quantitative preconcentration was $0.4 \mu \mathrm{g} \mathrm{L}^{-1} \mathrm{Cd}$ (II) with a preconcentration factor of 200. Recoveries from further diluted solutions were not quantitative. The limit of detection values was equal to $0.3 \mu \mathrm{g} \mathrm{L}^{-1} \mathrm{Cd}(\mathrm{II})$.

\section{Interference Study and Applicability}

The influence of matrix ions in water samples on the separation and recovery of $\mathrm{Cd}(\mathrm{II})$ ions was also

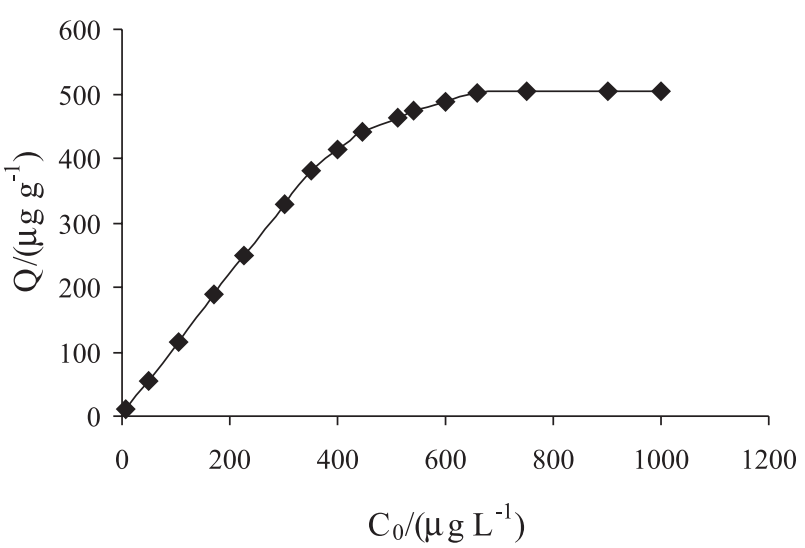

Figure 5. The effect of $\mathrm{Cd}(\mathrm{II})$ initial concentration on the adsorption quantity of the modified activated carbon. Other conditions: Modified activated carbon, $200 \mathrm{mg}$ and $\mathrm{pH}$ 6.0. 
investigated by passing different amounts of potential interfering ions plus $50.0 \mathrm{ng} \mathrm{mL} \mathrm{mL}^{-1} \mathrm{Cd}(\mathrm{II})$. The results showed that 10000-fold of alkaline and alkaline-earth ions, 5000-fold Zn(II), Fe(II), Ni(II), Pd(II), V(III), Mn(II), $\mathrm{Cu}(\mathrm{II}), \mathrm{Hg}$ (II), Al(III), Mo(VI), Co(II), Cr(III), Ag(I), Pb(II), chloride, nitrate, hydrogen carbonate, carbonate and sulfate did not interfere. The results confirm that the modified solid phase is highly selective for $\mathrm{Cd}(\mathrm{II})$ and interferences did not occur. The proposed method was used for three different water samples for Cd(II) determination: Zayandeh Roud River water (Isfahan city), tap water and waste water. The water samples were directly measured by the proposed method after filtering with a filter paper (Whatman No. 1) and spiking with various amounts of cadmium(II). For each sample, $250 \mathrm{~mL}$ of the spiked sample was passed through the column as explained in the recommended procedure. Then the $\mathrm{Cd}(\mathrm{II})$ contents in the washed solutions were determined by FAAS. In addition, the following reference materials: sewage sludge (CRM-144R), and sea water (CASS-4) were used to evaluate accuracy. CASS-4 reference material was spiked with various amounts of cadmium(II) to obtain the concentration of Cd(II). After that, cadmium(II) was determined using the separation/ preconcentration system. The results showed that the new solid phase is capable to separate and preconcentrate $\mathrm{Cd}(\mathrm{II})$ ions from water at trace levels (Table 3 ). The results for spiked samples and reference materials also proved the suitability of the solid phase for water analysis.

Table 3. Determination of Cd(II) in water samples $(n=4)$

\begin{tabular}{|c|c|c|c|}
\hline Sample & $\begin{array}{l}\text { Cd(II) Added / } \\
\quad\left(\mathrm{ng} \mathrm{mL}^{-1}\right)\end{array}$ & $\begin{array}{l}\text { Cd(II) Found / } \\
\quad\left(\text { ng } \mathrm{mL}^{-1}\right)\end{array}$ & $\begin{array}{c}\text { Recovery } \\
(\%)\end{array}$ \\
\hline \multirow[t]{4}{*}{ Tap water } & - & $4.8 \pm 0.3$ & - \\
\hline & 20.0 & $24.4 \pm 0.2$ & 98.0 \\
\hline & 30.0 & $35.1 \pm 0.5$ & 101.0 \\
\hline & 40.0 & $44.6 \pm 0.4$ & 99.5 \\
\hline Zayandeh Roud & - & $3.1 \pm 0.4$ & - \\
\hline \multirow[t]{3}{*}{ River water } & 20.0 & $23.3 \pm 0.6$ & 101.0 \\
\hline & 30.0 & $32.9 \pm 0.5$ & 99.3 \\
\hline & 40.0 & $43.4 \pm 0.4$ & 100.8 \\
\hline \multirow[t]{4}{*}{ Waste water } & - & $4.2 \pm 0.2$ & - \\
\hline & 20.0 & $24.5 \pm 0.3$ & 101.5 \\
\hline & 30.0 & $34.4 \pm 0.5$ & 100.7 \\
\hline & 40.0 & $43.9 \pm 0.4$ & 99.2 \\
\hline \multirow{2}{*}{\multicolumn{4}{|c|}{$\begin{array}{l}\text { CASS.4 Nearshore, } \\
\text { Seawater reference }\end{array}$}} \\
\hline & & & \\
\hline \multirow[t]{3}{*}{ material $^{\mathrm{a}}$} & - & $<\mathrm{DL}$ & - \\
\hline & 10.0 & $10.2 \pm 0.1$ & 102.0 \\
\hline & 20.0 & $19.8 \pm 0.29$ & 9.0 \\
\hline CRM-144R ${ }^{\mathrm{b}}$ & - & $1.89 \pm 0.10 \mu \mathrm{g} \mathrm{g}^{-1}$ & - \\
\hline
\end{tabular}

${ }^{\mathrm{a}}$ Certified value: $0.026 \pm 0.003 \mu \mathrm{g} \mathrm{L}{ }^{-1}$; < DL: below the detection limit;

${ }^{\mathrm{b}}$ Certified value: $1.84 \mu \mathrm{g} \mathrm{g}^{-1}$.

\section{Conclusions}

The method could be applied for the separation, preconcentration and selective determination of trace amounts of cadmium(II) as low as $0.3 \mathrm{ng} \mathrm{mL} \mathrm{m}^{-1}$. The modified activated carbon is stable for several treatments of sample solutions without the need for using any chemical reagent. The relative standard deviation for six independent determinations was $4.0 \%$ for cadmium $\left(20.0 \mathrm{ng} \mathrm{mL}^{-1}\right)$. Under the optimum conditions cadmium in aqueous samples was concentrated about 200 -fold. The recoveries of spiked cadmium(II) were in the range of 99-104\%. The recoveries obtained by the present solid phase are also comparable with the widely used and recently reported chelating resins. The obtained results are in good agreement with the certified values, which proved the applicability of the developed method to the quantitative separation/ preconcentration of cadmium in the sediment and sewage sludge samples. The lower acid concentration required for desorption of metal ion avoids the requirement of further dilution for AAS measurement and is among the advantage of the modified activated carbon, which also is not affected by leaching problems.

\section{Acknowledgments}

The authors are thankful to the Isfahan University of Technology Research Council and Centre of Excellence in Sensors (IUT) for supporting this work.

\section{References}

1. International Agency for Research on Cancer, IARC Monographs on the Evaluation of Carcinogenic Risk of Chemicals to Humans, IARC: Lyon, 1979.

2. Koester, C. J.; Siimonich, S. L.; Esser, B. K.; Anal. Chem. 2003, 75, 2813.

3. Viard, B.; Pihan, F.; Promeyrat, S.; Pihan, J.C.; Chemosphere 2004, 55, 1349.

4. Akba, O.; Baysal, A.; Hamamci, C.; Merdivan, M.; Gumgum, B.; Fresenius Environ. Bull. 2003, 12, 1412.

5. Prasad, K.; Gopikrishna, P.; Kala, R.; Rao, T. P.; Naidu, G. R. K.; Talanta 2006, 69, 938.

6. Liu, Y.; Chang, X.; Wang, S.; Guo, Y.; Din, B.; Meng, S.; Anal. Chim. Acta 2004, 519, 173.

7. Tuzen, M.; Soylak, M.; Elci, L.; Anal. Chim. Acta 2005, 548, 101.

8. Tuzen, M.; Parlar, K.; Soylak, M.; J. Hazard. Mater. 2005, 121, 79.

9. Pourreza, N.; Zavvar Mousavi, H.; Anal. Chim. Acta 2004, 503, 279. 
10. Santos, E. J.; Herrmann, A. B.; Ribeiro, A. S.; Curtius, A. J.; Talanta 2005, 65, 593.

11. Gama, E. M.; Lima, A. D. S.; Lemos, V. A.; J. Hazard. Mater. 2006, 136, 757.

12. Pereira, M. G.; Arruda, M. A. Z.; J. Braz. Chem. Soc. 2003, 14,39 .

13. Bortoleto, G. G.; Macarovscha, G. T.; Cadore, S.; J. Braz. Chem. Soc. 2004, 15, 313.

14. Soylak, M., Narin, I.; Chem. Anal. (Warsaw, Pol.) 2005, 50, 705 .

15. Ensafi, A. A.; Amini, M. K.; Mazloum, M.; J. Electrochem. Soc. 1999, 48,148 .
16. Khayamian, T.; Ensafi, A. A.; Benvidi, A.; Talanta 2006, 69, 1176.

17. Fan, J.; Wu, C.; Wei, Y.; Peng, C.; Peng, P.; J. Hazard. Mater. 2007, 145, 323.

18. Tewari, P. K.; Singh, A. K.; Talanta 2002, 56, 735.

19. Tewari, P. K.; Singh, A. K.; Fresenius J. Anal. Chem. 2000, 367, 562.

20. Yaman, M.; Gucer, S.; Analyst 1995, 120, 101.

Received: May 11, 2007

Web Release Date: December 17, 2007 